\title{
COGNITIVE FUNCTIONS, EPILEPTIC SYNDROMES AND ANTIEPILEPTIC DRUGS
}

\author{
PAULO R. M. BITTENCOURT*-MARIA JOANA MADER** \\ MONICA M. BIGARELLA **-MARIBEL P. DÓRO**- ANA M. GORZ* \\ TANIA M. MARCOURAKIS *** - ZULMA S. FERREIRA***
}

\begin{abstract}
SUMMARY - Cognitive function of patients on monotherapy specific for their epileptic syndrome has been studied infrequently. We evaluated 7 patients with symptomatic localised epilepsies (SEL) on phenytoin aged $30 \pm 12$ (mean \pm standard deviation) years, 8 with idiopathic generalised epilepsies on sodium valproate aged $18 \pm 4$ years, 16 with SEL on carbamazepine aged $28 \pm 11$ years, and 35 healthy controls aged $27 \pm 11$ years. All subjects were of normal intelligence, educated appropriately to age, and led productive lives in the community. Two of the patients on carbamazepine and one on valproate had less than five partial, absence or myoclonic seizures monthly, the remaining were controlled. Carbamazepine serum concentrations were $12 \pm 5 \mathrm{ug} / \mathrm{ml}$, phenytoin were $23 \pm 7$, and valproate were $62 \pm 23$ (mean $\pm \mathrm{sd}$ ). Tests included immediate recall and recognition for pictures, Stroop test, delayed recall and recognition of pictures. Patients on phenytoin and valproate performed significantly worse than controls on immediate recall, and patients on carbamazepine performed significantly worse than controls in Stroop test $(p<0,01)$. The results indicate relatively minor effects of the epileptic syndromes and of phenytoin, carbamazepine and valproate on cognition of patients with controlled epilepsy leading productive lives in the community. We conclude that the cognitive deficit found in chronic epileptic patients on polytherapeutic drug regimen must be multifactorial, and that future studies need to control for all possible variables in order to achieve meaningul results.
\end{abstract}

KEY WORDS: epilepsy, cognitive disorders, neuropsychology, phenytoin, carbamazepine, sodium valproate.

\section{Funções cognitivas, síndromes epilépticas o drogas antiepilépticas}

RESUMO - Função cognitiva de pacientes em monoterapia específica para sínđrome epiléptica tem sido pouco avaliada. Estudamos: 7 pacientes com epilepsias localizadas sintomáticas (SEL) utilizando fenitoína, com $30+12$ (média \pm desvio padrão) anos de iđade; 8 com epilepsias generalizadas idiopáticas utilizando valproato de sódio, com $18 \pm 4$ anos; 16 com SEL utilizando carbamazepina, com $28 \pm 11$ anos; 35 controles sadios, com $27 \pm 11$ anos. Todos tinham inteligência normal, educação apropriada para a idade e vidas produtivas na sociedade. Dois dos pacientes utilizando carbamazepina e um vaiproato de sódio tinham menos de 5 crises parciais, de ausência ou mioclônicas ao mês. Os outros pacientes tinham crises controladas há mais de 6 meses. As concentrações séricas de carbamazepina, fenitóna e valproato de sódio foram $12 \pm 5,23 \pm 7$ e $62 \pm 23 \mathrm{ug} / \mathrm{ml}$. Os testes incluíram memória e reconhecimento imediato e tardio de figuras e Stroop. Pacientes do grupo de fenitoina e valproato tiveram performance pior que controles em memória imediata; o grupo de carbamazepina foi plor que controles no teste de Stroop $(\mathrm{p}<0.01)$. Os resultados indicam efeitos discretos das sindromes epilépticas, de fenitoína, carbamazepina e valproato de sódio na cognição de pacientes com epilepsia eminentemente controlada e vida produtiva na comunidade. $O$ déficit de pacientes com epilepsia crônica sob regimes politerapêuticos deve ser multifatorial. Estudos futuros devem controlar, em seu planejamento, fatores causais possíveis para que seus resultados sejam relevantes.

PALAVRAS CHAVE: epilepsia, desordens cognitivas, neuropsicologia, fenitoina, carbamazepina, valproato de sódio.

Clinical Neurology $\left(^{*}\right)$ and Clinioal Psychology (**) Units, Hospital N.Sra. das Graças, Curitiba; and Neurology Investigation Center (***), University of São Paulo, São Paulo.

Dr. Paulo R. M. Bittencourt - Hospital Nossa Senhora das Gracas - Rua Alcides Munhoz 433 80510 Curitiba PR - Brasil. 
The various types of epileptic seizures, a number of antiepileptic drugs and factors in the previous history of patients with long-standing epilepsy have been associated with the genesis of the mental changes seen in patients with epilepsy 5 . In spite of a great number of studies that recently have attempted to clarify their relative role, it is as yet unclear whether epileptic patients have impairments that can be ascribed directly to one or more causative factors. Binnie et al.4, have looked at the effect of seizure discharges on verbal and spatial memory tasks, without taking into account the drugs patients were taking. This is just one example of the difficulties encountered when the variable to be assessed, in this case measurements of cognitive function, is subjected to the continuous or intermittent effects of a number if disparate pathophysiological mechanisms, such as length of history of epilepsy, type of seizure, brain damage of various etiologies including the recently described cytotoxicity related to NMDA and glutamate receptors 16 acute and chronic effects of drugs, among others 7,8 .

In a previous study 3 we have demonstrated that patients with active symptomatic localization related epilepsies 12 on therapeutic serum concentrations of phenobarbitone used in monotherapy, had a generalized deficit of cognition when compared to healthy controls. We concluded that the deficit could be related to phenobarbitone, to the past or present frequency of complex partial and generalized tonic clonic seizures, eventhough there was a difference in cultural and social background between patients and controls. In the present study we have attempted to go one step further, by evaluating in a prospective controlled manner a group of patients of superior economic and cultural status, with few if any seizures, with various epileptic syndromes 12, well controlled on high «therapeutic» serum concentrations of phenytoin, carbamazepine and valproate.

\section{METHODS}

Psychometric tests - The battery of quantitative measurements of cognitive function used in the study has been published and validated in epileptic and healthy subjects 3 . It can be carried out routinely and repeatedly on outpatients of a general hospital 6,9, lasts 25 minutes, and consists of six different tests based on simple material. In the immediate recall test and in the immediate recognition test the number of slides the subjects recall or identify correctly is the score. The stroop test measures the difference in time between identifying simple colours and colours with contradictory visual and verbal identification. It is a test of attention and concentration. After the Stroop test the recall and recognition procedures were repeated.

Subjects - All subjects agreed to participate in the study after being fully informed about procedure and consequences, as specified in the Declaration of Helsinki and in its ammendments. Patients were recruted personally by their private neurologists (PRMB or AMG), when the following criteria could be fulfilled: clear diagnosis of one of the epileptic syndromes (Comission, 1985); clear history of seizure type and frequency for at least the past year (Comission, 1981); normal mental state and satisfiactory social adaptation, as judged by the clinician; complete or practically complete control of seizures for at least six months, i.e., only patients with seizures that did not disturb their social, educational or professional activities were evaluated; stable monotherapeutic drug regimens with phenytoin, valproate or carbamazepine for longer than one year, with therapeutic serum concentrations as judged by laboratory determinations and clinical status, i.e., patients could not have complaints suggestive of antiepileptic drug toxicity. All patients had in their files detailed neurological, medical and psychiatric history, family history, various physical examinations, and complete neurological and medical investigations, including $C T$ scan, routine and sleep EEG, but not MRI. The majority had been initially refered because of refractory epileptic seizures and had undergone major drug changes before becoming seizure-free. The population of controls consisted of medical and nursing students or staff, as well as of members of the patients' families, chosen to match age, sex and social and cultural characteristics of the patients. The psychologist in charge of the cognitive battery was unaware of the nature of the subjects, and of clinical details such as drug therapy, diagnosis, history of seizures.

Blood samples were collected immediately after testing of cognitive function. The serum was frozen and subsequently drug concentrations were determined by gas-liquid chromatography by a laboratory affiliated to an international quality-control scheme (TM and ZSF). Statistical analysis of the results of the tests of cognitive function was carried out by the Kruskal-Wallis one-way analysis of variance. Once significant variations were 
found the Mann-Whitney $U$ test was employed to test for differences between the groups of patients and controls, but not among the groups of patients.

\section{RESULTS}

Groups of 35 control and 31 epileptic subjects on monotherapy with phenytoin (7), valproate (8) or carbamazepine (16) were evaluated. Their demographic details and educational level are shown in Table 1. The patients on phenytoin and carbamazepine had symptomatic epilepsies with localization, and the patients on sodium valproate had idiopathic generalised epilepsies (Commission, 1985). The differences among the groups with regard to age and educational level are related to the ages of occurrence of the specific syndromes. All patients were well adapted to productive life in the community, and the educational level of the patients is similar to that of the controls.

The mean monthly seizure frequency for each seizure type in the groups of patients on carbamazepine, phenytoin or valproate is shown in Table 2 . Although seven patients had complex partial and three had simple partial seizures in the group on carbamazepine, the monthly frequency was very low. One of the subjects on phenytoin had complex partial seizures, while in the group on valproate one patient had tonic-clonic, absence and myoclonic seizures.

Table 1 - Demographic details of 35 healthy control subjects and 31 epileptic patients on monotherapy with carbamazepine (CBZ), phenytoin (DPH) or sodium valproate (VAL).

\begin{tabular}{|c|c|c|c|c|c|c|c|c|}
\hline & \multirow[b]{2}{*}{$\mathbf{n}$} & \multirow[b]{2}{*}{ Females } & \multicolumn{3}{|c|}{ Age (years) } & \multicolumn{3}{|c|}{ Education } \\
\hline & & & range & mean & sd & Prim & Sec & Sup \\
\hline Controls & 35 & 20 & 17-62 & 27 & 11 & 4 & 23 & 8 \\
\hline CBZ & 16 & 11 & $11-46$ & 28 & 11 & 7 & 2 & 7 \\
\hline VAL & 8 & 5 & $12-25$ & 18 & 4 & 1 & 5 & 2 \\
\hline DPH & 7 & 4 & $17-56$ & 30 & 12 & 1 & 4 & 2 \\
\hline
\end{tabular}

n, number; sd, standard deviation; Prim, complete primary school; sec, complete secondary school; Sup, university degree.

Table $\&$ - Mean manthly frequency in the 6 months previous to the study of complex partial (CP), simple sartial (SP), generalized tonic-clonic (GTC), absence (ABS) or myoclonio (MYOCL) seizures in 31 epileptic patients on monotherapy with valproate (VAL), phenytoin $(D P H)$, or carbamazepine (CBZ).

\begin{tabular}{|c|c|c|c|c|}
\hline $\mathbf{N}$ & & $\begin{array}{c}\text { CBZ } \\
16\end{array}$ & $\begin{array}{c}\text { VAL } \\
8\end{array}$ & $\begin{array}{c}\mathrm{DPH} \\
7\end{array}$ \\
\hline \multirow[t]{3}{*}{$\mathrm{CP}$} & $\mathrm{n}$ & 11 & 0 & 1 \\
\hline & $\mathrm{m}$ & 1.45 & 0 & 0.4 \\
\hline & $s d$ & 5 & 0 & 1.3 \\
\hline \multirow[t]{3}{*}{$\mathbf{S P}$} & $\mathbf{n}$ & 3 & 0 & 0 \\
\hline & $\mathrm{m}$ & 0.78 & 0 & 0 \\
\hline & $\mathbf{s d}$ & 2.5 & 0 & 0 \\
\hline \multirow[t]{3}{*}{ GTC } & $\mathbf{n}$ & 0 & 1 & 0 \\
\hline & $\mathrm{m}$ & 0 & 0.06 & 0 \\
\hline & $\mathbf{s d}$ & 0 & 0.18 & 0 \\
\hline \multirow[t]{3}{*}{ ABS } & $\mathbf{n}$ & 0 & 1 & 0 \\
\hline & $\mathbf{m}$ & 0 & 7.5 & 0 \\
\hline & sd & 0 & 21.2 & 0 \\
\hline MYOCL & & 0 & $+++(1)$ & 0 \\
\hline
\end{tabular}

$N$, total number in the group; $n$, number with seizure type; $m$, mean; sd, standard deviation. 
Table 3 - Raw results of performances in the tests of cognitive function.

\begin{tabular}{|c|c|c|c|c|c|c|c|c|}
\hline \multirow[t]{2}{*}{$\mathbf{N}$} & \multicolumn{2}{|c|}{$\begin{array}{c}\text { Controls } \\
\mathbf{3 5}\end{array}$} & \multicolumn{2}{|c|}{$\begin{array}{c}\text { Carbamazepine } \\
16\end{array}$} & \multicolumn{2}{|c|}{$\begin{array}{c}\text { Valproate } \\
8\end{array}$} & \multicolumn{2}{|c|}{$\begin{array}{c}\text { Phenytoin } \\
7\end{array}$} \\
\hline & $\mathrm{m} \pm \mathrm{sd}$ & range & $\mathrm{m} \pm \mathbf{s d}$ & range & $\mathrm{m} \pm \mathbf{s d}$ & range & $\mathbf{m} \pm \mathbf{s d}$ & range \\
\hline $\begin{array}{l}\text { Imrnediate } \\
\text { recall }\end{array}$ & $14 \pm 2$ & $9-20$ & $13 \pm 3$ & $7-17$ & $12 \pm 2 *$ & 10-15 & $12 \pm 2 *$ & $8-15$ \\
\hline $\begin{array}{l}\text { Late } \\
\text { recall }\end{array}$ & $16 \pm 3$ & $9-20$ & $15 \pm 4$ & $r-19$ & $16 \pm 2$ & $12-17$ & $15 \pm 3$ & $11-19$ \\
\hline $\begin{array}{l}\text { Immediate } \\
\text { recognition }\end{array}$ & $39 \pm 1$ & $36-40$ & $38 \pm 3$ & $31-40$ & $39 \pm 1$ & $37-40$ & $38 \pm 1$ & $37-40$ \\
\hline $\begin{array}{l}\text { Late } \\
\text { recognition }\end{array}$ & $39 \pm 2$ & $33-40$ & $37 \pm 3$ & $28-40$ & $39 \pm 1$ & $37-40$ & $39 \pm 1$ & $37-40$ \\
\hline $\begin{array}{l}\text { Stroop } \\
\text { test }\end{array}$ & $11 \pm 7$ & $1-28$ & $15 \pm 8 *$ & $5-2 \theta$ & $12 \pm 7$ & $2-21$ & $14 \pm 8$ & $6-30$ \\
\hline
\end{tabular}

* indicates the groups with performances significantly worse than the control group $(p<0.01)$.

COGNTTIVE FUNCTION AND EPTIEPSY

SERUM CONCENRRATIONS (ng/ml)
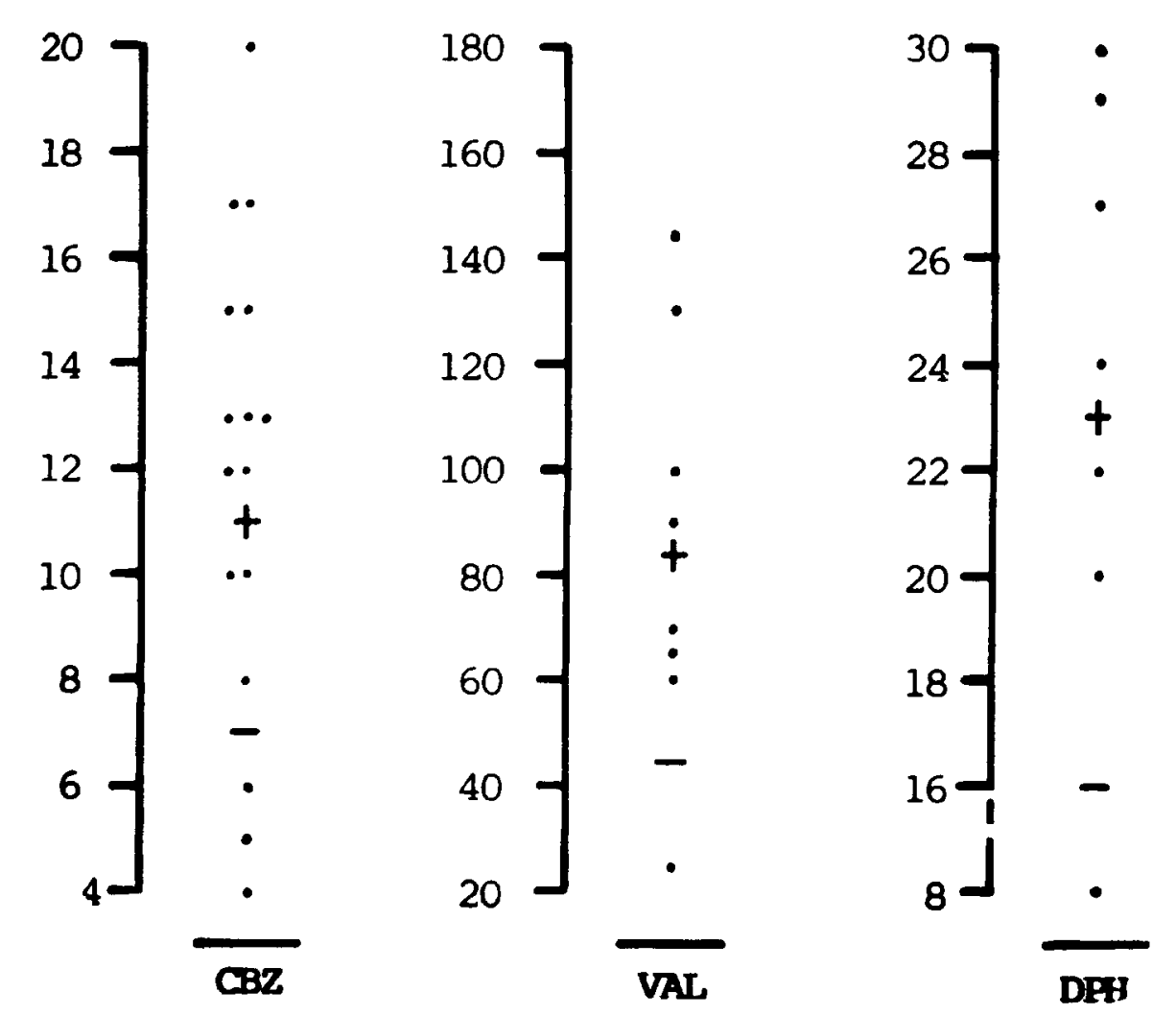

Fig. 1 - Serum concentrations on phenytoin, carbamazepine and sodium valproate in three groups of subjects treated with monotherapy, respectively for symptomatic localised epilepsies and idiopathic generalised epilepsies.

The serum concentrations of valproate, carbamazepine and phenytoin are shown in Figure 1. The mean concentrations in the three groups are high and some subjects had concentrations above the usually accepted therapeutic range 22, in spite of the observation that none of the subjects was complaining of symptoms of acute or chronic toxicity.

The results of psychometric tests are shown on Table 3. Statistical analysis indicated that phenytoin and valproate-treated subjects had worse immediate recall than controls, and that carbamazepine-treated subjects had worse performance in the stroop test than controls. It is likely that the phenytoin-treated group, if made up of greater number of subjects, would also have had a worse performance than controls in the Stroop test. 


\section{COMMENTS}

The results indicated that patients on sodium valproate because of idiopathic generalised epilepsies have a deficit of retention skills when compared to controls. It is impossible to ascertain whether this effect was due to the epileptic syndrome or to the drug itself. The finding of similar deficit in patients with symptomatic localised epilepsy on phenytoin appears to be specific for the drug, as it was not found in the carbamazepine-treated patients with the same syndrome.

The worse performance of the carbamazepine-treated patients on the Stroop test appeared to be related to the epileptic syndrome, in view of the similar performance of the phenytoin-treated patients, which did not reach statistical significance because of the small number of patients. These findings may indicate that symptomatic localised epilepsy leads to a deficit of attention, but the possibility that both phenytoin and carbamazepine lead to this effect cannot be ruled out. The results of this study contrast with those obtained with the same experimental design and cognitive battery 3 , in which patients with symptomatic localized epilepsy with frequent complex partial and tonic-clonic seizures, treated with therapeutic serum concentrations of phenobarbitone, displayed a generalized and severe impairment in all the tests used. The present results show minor differences as compared to that study. It would appear that patients with idiopathic generalized epilepsies, symptomatic localized epilepsies or indetermined epilepsies, treated with high «therapeutic» serum concentrations of valproate, carbamazepine and phenytoin have very mild impairment of some cognitive skills. The pharmacological or syndromic specificity of these changes cannot be ascertained on the basis of the present or other studies published 2 .

On the one hand patients with active epilepsy on phenobarbitone have severe cognitive deficits, on the other patients with inactive epilepsy have few if any deficits, in spite of high therapeutic concentrations of carbamazepine, valproate and phenytoin. These are individuals that achieve usual good standards of middle class in the developed south of Brasil, from the educational, social, professional and economic points of view. Another group, on phenobarbitone with uncontrolled epilepsy 3 achieved less in professional, educational and social measures. It would appear that frequent tonic-clonic and complex partial seizures, as well as treatment with phenobarbitone, are related to worse cognition and lower achievement. On the other hand, in subjects that had active disease for a period short enough not to lead to a drop in social, educational or professional skills, controlled epilepsy, valproate, carbamazepine or phenytoin had little effect on cognition and, apparently, on achievement. These findings are in contrast to experiments in healthy subjects that found effects of both valproate and phenytoin but not carbamazepine in a similar battery of tests of cognitive functions 29,31 . The findings of Aman et al.2 are of interest, as they concluded that high valproate levels in the blood stream or greater severity of epilepsy led to cognitive impairment.

Few of the many studies of cognition in epilepsy can be interpreted in a clear realistic manner. The studies McLeod et al.19 and Camfield et al.10 related deficits in performance to use of phenobarbitone, but could not rule out the possibility that seizure frequency or type could influence their findings. The work of Cull, Thompson and Trimble 13,14,26-31 suffered from the very basic problem of experiments carried out either in healthy subjects with inappropriate serum concentrations of antiepileptic drugs for short periods of time, or in long-term residents of epilepsy centers with multiple handicaps from the physical, social and mental points of view. It is not surprising that even a decade after these experiments were started they have not yet achieved clear results $15,23,32$ while clinicians in the front line see their patienets graduating from high school and entering university at the same rate as their patients with migraine, for example.

The cognitive deficit of people with multiple handicaps is very likely to oscillate enourmously from one period in time to the next, because of the many variables in concomitant operation. Unless all variables are controlled for, the results may have very little meaning indeed, or even produce statistical noise. Although elegant studies such as that of Aldenkamp and colleagues ${ }^{1}$ demonstrated that controlled release carbamazepine had less cognitive side-effects during repeated measurements in the same day than usual carbamazepine, they did not specify what other drugs patients were on, and how these concentrations oscillated during the period of study. In one of the few studies that considered seizure types and frequencies, other methodological problems hindered definite conclusions 24,25. Most recent authors aggree that seizure 
type and frequency needs to be evaluated more carefully $13,14,21,24,25$. A recent double-blind, triple crossover study by Meador et al.20, using a comprehensive battery of behavioural tests in groups of patients with complex partial seizures on phenobarbitone, phenytoin and carbamazepine, demonstrated that phenobarbitone produced the worst results, and failed to show differences between the two other drugs. The results of the present study and of that of Bigarella et al.3 are in agreement with these findings.

Memory and verbal learning ability have been shown to be impaired in patients with complex partial seziures originated in the left but not right temporal lobes 18 . Similarly, subclinical epileptiform discharges from the left temporal lobe have been shown to lead to transitory cognitive verbal impairment, while discharges from the right temporal lobe were related to similar but spatial cognitive changes 4 . Galassi et al.17 reported improvement in a measure obtained form pooling of various neuropsychological tests, in patients withdrawn from phenytoin therapy because they had been free of seizures for a few years. Unfortunately, apparently only five subjects finished their very long-term study.

A criticism valid to the present study and to others in the field of cognition and epilepsy is the lack of clearly validated tests from the anatomical point of view. Until this is achieved it will be problematic to prove the specificity of drug or disease effects on the variables measured. Until it is demonstrated that a test corresponds to damage in a specific neuronal circuit, many confirmations of experimental findings, such as those on Stroop test, memory and retention reported here, will be necessary.

In conclusion, the present and other studies indicate that phenobarbitone, frequent tonic clonic or complex partial seizures, and perhaps neuronal damage associated with long-standing epilepsy have definite effects on cognition. Valproate, phenytoin and carbamazepine, even when used chronically with serum concentrations at the top of the so-called «therapeutic» range of serum concentrations have mild effects

on few tests.

Acknowledgement - The authors wish to thank Ms. M. G. Calderarl and Mrs. M. Simioni for secretarial assistance and helpful comments.

\section{REFERENCES}

1. Aldenkamp AP, Alpherts WCJ, Moerland MC, Ottevanger N, Van Parys JAP. Controlled release carbamazepine: cognitive side effects in patients with epilepsy. Epilepsia 1987. 28:507-514.

2. Aman MG, Werry JS, Paxton JW, Turbott SH. Effects of sodium valproate on psychomotor performance in children as a function of dose, fluctuation in concentration and diagnosis, Epilepsia 1987, 28:115-124.

3. Bigarella MM, Mader MJ, Doro MP, Gorz AM, Marcourakis T, Tsanaclis L, Bittencourt PRM. Cognitive functions of epileptic patients on monotherapy with phenobarbitone and healthy controls. Arq Neuropsiquiatr 1991, 49:136-141.

4. Binnie CD, Kasteleijn-Nolst, Trenité DGA, Smith AM, Wilkins AJ. Interactions of epileptiform EHEG discharges and cognition. Epilepsy Res 1987, 239-245.

5. Bittencourt PRM. Cerebral and cerebellar atrophy in patients with severe epilepsy: a preliminary report. In Oxley J, Janz D, Meinardi H (eds): Chronic Toxicity of Antiepileptic Drugs. New York: Raven Press, 1983, p 237-246.

6. Bittencourt PRM. Epilepsy in developing countries: Latin American aspects. In Laidlaw J. Richens A, Oxley J (eds): Textbook of Epilepsy. Ed 3. Edinburgh: ChurchillLivingstone 1988, p 518-527.

7. Bittencourt PRM, Perucca E, Crema A. Cerebellar toxicity of antiepileptic drugs. In Blum K, Manzo L (eds): Neurotoxicology. New York: Marcel Dekker 1984, p 233-250.

8. Bittencourt PRM, Richens A. Assessment of antiepileptic drug toxicity by eye movements. In Buser PA, Cobb, WA, Okuma $T$ (eds): Kyoto Symposia, EEG and Clinical Neurophysiology, Suppl 36, Amsterdam: Elsevier 1982, p 467-481.

9. Bittencourt PRM, Turner M. Epilepsy in Latin America. In Dam M Gram L (eds): International Epileptology, New York: Raven Press 1991, p 807-820.

10. Camfield AA, Chaplin S, Doyle AM. Side effects of phenobarbital in toddlers: behavioural and cognitive aspects. J Pediatrics 1980, 95:361-365.

11. Comission on Classification and Terminology of the International League Against Epilepsy. Proposal for revised clinical and electroencephalographic classification of epileptic seizures. Epilepsia 1981, 22:489-501. 
12. Commission on Classification and Terminology of the ILAE. Proposal for classification of epilepsies and epileptic syndromes. Epilepsia 1985, 26:268-278.

13. Cull CA. Cognitive function and behaviour in children. In Trimble MR, Reynolds EH (eds): Epilepsy, Behaviour and Cognitive Function Chichester: John Wiley and sons 1988, p 97-111.

14. Cull CA, Trimble MR. Anticonvulsant benzodiazepines and performance. Internat Congress Symposium Series, Royal Soc Med 1985, 74:121-128. London: Academic Press.

15. Dodrill CB. Correlates of generalized tonic-clonic seizures with intellectual, neuropsychological, emotional, and social function in patients with epilepsy. Epilepsia 1986. $27: 399-411$.

16. Foster AC, Fagg GE. Taking apart NMDA receptors, Nature 1987, 329:395-396.

17. Gallassi R, Morreale A, Lorusso S, Ferrari M, Procaccianti G, Lugaressi E, Baruzzi A. Cognitive effects of phenytoin during monotheraphy and after withdrawl. Acta Neurol Scand 1987, $75: 258-261$.

18. Hermann BP, Wyler AR, Richey ET, Rea JH. Memory functions and verbal learning ability in patients with complex partial seizures of temporal lobe origin. Epilepsia 1987. 28:547-554.

19. MacLeod CM, Dekaban AS, Hunt E. Memory impairment in epileptic patients: selective effect of phenobarbitone concentration. Science 1978, 202:1102-1104.

20. Meador KJ, Loring DW, Huh K, Gallagher BB, King DW. Comparative cognitive effects of anticonvulsants. Neurology 1990, 40:391-394.

21. Ossertin J. Methods and problems in the assessment of cognitive function in epileptic patients. In Trimble MR, Reynolds EM (eds): Epilepsy, Behaviour and Cognitive Function, Chichester: John Wiley \& Sons 1988, p 9-26.

22. Rimmer E, Richens A. Clinical pharmacology. In Laidlaw J, Richens A, Oxley J (eds): Textbook of Epilepsy. Ed 3. Edinburgh: Churchill-Livingstone 1988, p 422-483.

23. Rodin E, Schmaltz S, Tuitly G. Intellectual functions of patients with childhood-onapt epilepsy. Dev Med Child Neurol 1986, 28:25-33.

24. Smith DB. Anticonvulsants, seizures and performance: the Veteran's Administration experience. In Trimble MR, Reynolds EH (eds): Epilepsy, Behaviour and Cognitiva Function. Chichester: John Wiley \& Sons 1988, p 67-78.

25. Smith DB, Craft RB. VA Cooperative Study Group. Differential neurotoxicity of four major anticonvulsants (Abstr). Ann Neurol 1985, 18:119.

26. Thompson PJ, Huppert FA, Trimble MR. Phenytoin and cognitive function: effects on normal volunteers and implications for epilepsy. Br J Clin Psychol 1981, 20:155-162.

27. Thompson PJ, Trimble MR. Sodium valproate and cognitive functioning in normal volunters.' Br J Clin Pharmacol 1981, 12:179-182.

28. Thompson PJ, Trimble MR. Clobazam and cognitive functions: effects in healthy volunteers. In Clobazam Internat Congress Symposium Series, Royal Soc Med 1981, 43:33-38. London: Academic Press.

29. Thompson PJ, Trimble MR. Anticonvulsant drugs and cognitive functions. Epilepsia 1982, $33: 531-544$.

30. Thompson PJ, Trimble MR. Comparative effects of anticonvulsant drugs on cognitive functioning. $\mathrm{Br} \mathrm{J}$ Clin Practice 1982, 18 (Suppl): 154-156.

31. Thompson PJ, Trimble MR. Anticonvulsant serum levels: relationship to impairments of cognitive functioning. J Neurol Neurosurg Psychiatry 1983, 46:227-233.

32. Vining EPG. Cognitive dysfunction associated with antiepilentic drug therapy. Epilepsia 1987, 28 (Suppl 2): S18-S22. 